\title{
EFFECT OF RATIONS INCLUSION GUAVA BY-PRODUCTS WITH OR WITHOUT PROBIOTIC ON GROWTH PERFORMANCE OF GROWING GOAT KIDS
}

\author{
Wafaa, M.A. Ghoneem and A.E.M. Mahmoud \\ Animal Production Department, Faculty of Agriculture, Cairo University, 12613, Giza, Egypt.
}

(Received 14/1/2015, accepted 15/3/2015)

\section{SUMMARY}

\begin{abstract}
$\mathrm{T}$ This study aimed to determined effect of guava by-product (GBP) substitution at level $20 \%$ of concentrate feed mixtures with or without commercial probiotic (Enviva $\left.{ }^{\circledR} P R O\right)$ on the performance of growing goat kids. Twenty-four growing Zaraibi male kids weighted $15 \mathrm{~kg}$ body weight in average and 7 months old; assigned to three groups ( 8 in each). Feeding trial lasted for 90 days. Animals were fed clover hay plus CFM (R1), CFM including 20\% GBP (R2) or supplemented with probiotic, $5 \mathrm{~g} / \mathrm{h} /$ day (R3). Results showed insignificant differences in most nutrients and fiber fractions digestibilities and TDN values among treatments. Ruminal $\mathrm{pH}$ and TVFẢs values did not differ significantly among treatments. While, ruminal NH3-N concentrations were significantly $(\mathrm{p}<0.05)$ higher with R2 and R3 compared to R1. Results indicated that neither GBP nor probiotic had an adverse impact on goats health which all blood parameters were within the normal range. There were no significant differences among treatments in total and average daily gain. Both R2 and R3 had lower total DM and TDN intake compared to R1. Meanwhile R3 group had the best feed conversion and the highest economical efficiency. It could be concluded that guava by-product (GBP) at level $20 \%$ of CFM and probiotic supplementation $(5 \mathrm{~g} / \mathrm{h} / \mathrm{d})$ in growing kids goats rations had no adverse effects on productive performance with enhancing in economical efficiency.
\end{abstract}

Keywords: guava by-product, probiotic, goat kids, performance.

\section{INTRODUCTION}

The high cost and scarcity of conventional feed ingredients constitute major problems facing commercial production of ruminants in the developing countries of the world. In order to compensate the feed shortage and to reduce feeding cost attempts have been made to use agricultural and food industrial by-products as feed ingredients (Karkoodi et al., 2012). In Egypt the quantity of agro-industrial byproducts produced is relatively large most of these by-products are dumped or burned causing environmental pollution and consequently health hazards. The agro industrial by-products are less fibrous, more concentrated, highly nutritious and less costly as compared to crop residues (Aguilera, 1989). On the other side, they have a high moisture content so drying processes are needed.

Guava by-products (GBP; pulp, peel, seeds and inedible fruits) is produced as a waste of canning industry and yet was not fully evaluated as a feedstuff for animal. Lipids content of guava seeds was found to range from 8.9 to $9.4 \%$ (Opute, 1978 and Aly, 1981). The protein content of guava seeds was $9.73 \%$ on DM basis and the major amino acids constituted about $67 \%$ of the total amino acids (Adsule and Kadam, 1995). The GPB is a rich source of vitamin C 200-300 mg/100 g (Holland et al., 1991). The pulp and peel fractions of guava had high content of fiber (48.55-49.42\%) and extractable polyphenols (2.62-7.79\%) methoxylated pectin, which can be a suitable source of natural antioxidants (Marquina et al., 2008). The metabolizable Energy value of sun dried GBP was $2200 \mathrm{kcal} / \mathrm{kg}$ (El-Deek, et al., 2009). Marquina et al (2008) indicated that guava by-product could be used in Broiler and Finishing Diets. Also, El-Deek, et al. (2009) found that sun dried GBP could be included at a level of $15 \%$ in laying hen diets without adverse effect on productive performance and egg quality traits.

Maximization fiber utility of GBP could be achieved by different approaches such as probiotics addition that improve nutrient digestibility (Abd El-Ghani, 2004) reduce other pathogenic micro- 
organisms by competing for the provision of nutrients and other growth factors (Rolfe, 2000). They are also known to increase ruminal pH (Mohamed et al., 2009 and Paryad and Rashidi, 2009), total volatile fatty acids (VFA's) and ruminal biomass (Newbold et al., 1996) and thus influence the cellulolytic activity and microbial protein synthesis and fiber degradation (Martin and Nisbet, 1990 and Yoon and Stern, 1996). Meanwhile, many studies recorded a positive effect of probiotics supplementation on nutrients intake, body weight gain and feed conversion ratio (FCR) in ruminants (Chiofalo et al., 2004 and Whitley et al., 2009).

The objective of this study was to evaluate the effect of using $20 \%$ GBP at level of $20 \%$ of concentrate feed mixture (CFM) in goats ration either with or without probiotic on performance, digestibility, feeding value, rumen liquor, some blood parameters. Meanwhile, on economic study was hold.

\section{MATERIALS AND METHODS}

\section{Experimental animals and ration:}

Twenty four Zaraibi kids averaged $(15 \mathrm{~kg}$ ) body weight; 7 months old were divided into 3 groups of 8 animals according to their live weight. Animal groups were as follows:- R1 (control ration): clover hay plus concentrate feed mixture (CFM), R2: clover hay plus CFM substituted with $20 \%$ guava by-products (GBP) and R3: clover hay plus CFM substituted with $20 \%$ guava by-products (GBP) and supplemented 5 $\mathrm{g} / \mathrm{h} / \mathrm{d}$ probiotic (Enviva ${ }^{\circledR} \mathrm{PRO}$ ). Roughage concentrate ratio was 30:70. The probiotic (Enviva ${ }^{\circledR} \mathrm{PRO}$ ) was daily mixed manually with CFM. The probiotic is a blend of three species of Bacillus subtills and its byproducts. The concentrate feed mixtures are presented in Table (1). The experiment lasted 90 days.

Table (1): Formulation of the experimental concentrate feed mixtures (CFM \%).

\begin{tabular}{lcc}
\hline Feed ingredients, $\%$ & Control & GBP \\
\hline yellow corn & 65 & 51 \\
wheat bran & 15 & 12 \\
soybean meal & 15 & 12 \\
GBP* & - & 20 \\
Premix & 1.2 & 1.2 \\
common salt & 0.8 & 0.8 \\
Limestone & 3 & 3 \\
\hline * & &
\end{tabular}

\section{Feeding procedures:}

The growing kids were fed CFM and clover hay twice daily to cover their total requirements according to NRC (1981). Water was allowed freely all the day round. Orts were collected just before offering the next day feed. Kids were weighed every two weeks before morning feeding after $15 \mathrm{~h}$ of fasting. Rations were adjusted every two weeks according to body weight changes (Khattab et al., 2011). Body weight gain was recorded and daily feed intake was calculated. Dry matter, total digestible nutrients (TDN) and digestible crude protein (DCP) intake were calculated. Feed conversion ratio was calculated as follow (intake g/daily gain $\mathrm{g}$ ) for DM and TDN.

\section{Digestion trials:}

After 90 days, three kids from each group were used in digestion trials to evaluate the experimental rations. In these trials the experimental rations consisted of $70 \% \mathrm{CFM}$ and $30 \%$ clover hay. Each trial was divided into two stages: a preliminary 21-day period to allow the animals to adapt to each feed, and a 7-day experimental period during which voluntary feed intake was measured and total collection of feces.

\section{Sampling and analytical procedures:}

\section{Chemical analysis:}


Feeds and feces were analyzed for proximate analyses (A.O.A.C., 2000). Nitrogen free extract was calculated by difference. The NDF and ADF were determined according to Van Soest et al. (1991). Cellulose and hemi-cellulose were calculated by difference according to the following equations: cellulose $=\mathrm{ADF}-\mathrm{ADL}$ and hemi-cellulose $=\mathrm{NDF}-\mathrm{ADF}$.

\section{Rumen liquor sampling:}

Rumen liquor samples were taken just before morning feeding, three and six hours post feeding during collection period of digestion trials. Samples of rumen liquor were strained through two layers of cheesecloth and its $\mathrm{pH}$ was immediately measured after collection by using $\mathrm{pH}$ meter. Strained rumen liquor (SRL) samples were acidified with $0.1 \mathrm{~N}$ hydrochloric acid and concentrated orthophosphoric acid and stored by freezing for determination of total volatile fatty acids (TVFA's). Ammonia was determined according to (Preston, 1995). Total VFA was determined by steam distillation according to Cunniff (1997).

\section{Blood parameters:}

Blood samples were withdrawn from all the experimental animals. The blood samples were taken from the jugular vein in dry clean glasses tubes using heparin as anticoagulant and then centrifuged for 15 minutes at $4000 \mathrm{rpm}$ to obtain plasma. Blood plasma total protein and creatinine were determined according to Tietz (1986) and Tietz et al. (1990), albumin was determined according to Doumas et al. (1971), blood plasma urea was determined according to Patton and Grouch (1977). Alanin amino transferase (ALT) and activity of aspartate transfearse (AST) were determined by the methods of Young (1997).

\section{Statistical analysis:}

Data were analyzed using the general linear model procedure of SAS (2001, Ver.8.02, SAS Institute Inc., Cary, NC, USA). The differences among means were separated according to Duncan New Multiple Range Test (Duncan, 1955).

\section{RESULTS AND DISCUSSION}

\section{Chemical composition and fiber fractions:}

Results of chemical composition and fiber fractions of clover hay, concentrate feed mixture, guava byproduct and experimental rations are shown in Table (2). Data of chemical composition indicated that GBP had low CP content (5.21\%) and high CF (61.44\%) and fiber fractions $(75.77 \%$ NDF and 59.62\% ADF) contents. El-Deek et al. (2009) recorded higher CP and lower CF contents of GBP being 9.08 and $39.50 \%$, respectively. This may be due to the nature of guava by products. The previous observations explained lower $\mathrm{CP}$ and higher contents of $\mathrm{CF}$ and fiber fractions in rations contained GBP compared with control ration.

Table (2): Chemical composition of the experimental clover hay, concentrate feed mixture, guava by-products and the experimental rations

\begin{tabular}{lccccc}
\hline \multirow{2}{*}{ Item } & \multicolumn{3}{c}{ Feedstuffs } & \multicolumn{2}{c}{ Experimental rations } \\
\cline { 2 - 5 } & CFM & CH & GBP & Control & GBP20 \\
\hline DM & 91.09 & 93.05 & 93.12 & 9.61 & 92.01 \\
Chemical composition, \% (DM basis) & & & & \\
OM & 94.10 & 92.69 & 97.26 & 93.73 & 94.11 \\
Ash & 5.90 & 7.31 & 2.74 & 6.27 & 5.89 \\
CP & 13.59 & 15.99 & 5.21 & 14.23 & 13.15 \\
EE & 6.02 & 1.55 & 4.69 & 4.83 & 4.49 \\
CF & 6.39 & 38.73 & 61.44 & 15.14 & 24.04 \\
NFE & 68.10 & 36.42 & 25.92 & 59.53 & 52.43 \\
Fiber fraction, \% & & & & & 36.37 \\
NDF & 19.23 & 49.83 & 75.77 & 27.35 & 18.00 \\
ADF & 8.98 & 42.97 & 59.62 & 4.45 & 26.32 \\
ADL & 2.66 & 9.41 & 25.06 & 13.55 & 18.83 \\
Cellulose & 6.32 & 33.56 & 34.56 & 9.35 & 10.05 \\
Hemi-cellulose & 10.25 & 6.86 & 16.15 & & \\
\hline
\end{tabular}


CFM: Concentrate feed mixture, CH: Clover hay,GBP: Guava by-products, Control: clover hay plus CFM and GBP20: clover hay plus CFM substituted with 20\% GBP. DM: Dry matter, OM: Organic matter, CP: Crude protein, EE: Ether extract, CF: Crude fiber, NFE: Nitrogen free extract, NDF: Neutral detergent fiber, ADF: Acid detergent fiber and ADL: Acid detergent lignin.

\section{Nutrients digestibility and nutritive values:}

Nutrients digestibility and nutritive values of the experimental rations are presented in Table (3). In general, no significant differences in most nutrients and fiber fractions digestibilities and nutritive value as TDN were observed among treatments. While, rations containing GBP either with or without probiotic (R2 and R3) recorded higher digestibility of NFE and lower nutritive value as DCP than control.

Table (3): Nutrients digestibility and nutritive values of the experimental rations

\begin{tabular}{|c|c|c|c|c|}
\hline \multirow{2}{*}{ Item } & \multicolumn{3}{|c|}{ Experimental rations } & \multirow[b]{2}{*}{$\pm \mathrm{SE}$} \\
\hline & R1 & $\mathrm{R} 2$ & R3 & \\
\hline \multicolumn{5}{|c|}{ Apparent digestibility, \% } \\
\hline $\mathrm{DM}$ & 77.09 & 73.56 & 75.85 & 0.77 \\
\hline OM & 77.91 & 74.95 & 77.08 & 0.70 \\
\hline $\mathrm{CP}$ & 73.75 & 71.75 & 73.94 & 0.71 \\
\hline $\mathrm{CF}$ & 60.74 & 55.47 & 58.31 & 1.23 \\
\hline $\mathrm{EE}$ & 84.16 & 85.63 & 86.12 & 0.44 \\
\hline NFE & $72.76^{\mathrm{b}}$ & $73.76^{\mathrm{ab}}$ & $75.70^{\mathrm{a}}$ & 0.56 \\
\hline \multicolumn{5}{|l|}{ Fiber fractions: } \\
\hline $\mathrm{NDF}$ & 57.41 & 52.48 & 54.34 & 1.27 \\
\hline $\mathrm{ADF}$ & 58.25 & 53.03 & 57.11 & 1.29 \\
\hline Cellulose & 66.37 & 64.33 & 66.13 & 0.85 \\
\hline $\begin{array}{l}\text { Hemi-cellulose } \\
\text { Nutritive values }\end{array}$ & 55.79 & 51.02 & 49.10 & 1.49 \\
\hline TDN & 72.15 & 70.10 & 72.13 & 0.63 \\
\hline DCP & $10.49 \mathrm{a}$ & $9.43 \mathrm{~b}$ & $9.74 b$ & 0.18 \\
\hline
\end{tabular}

Results showed that including GBP in goats ration (R2) decreased digestibilities ( $\mathrm{P}>0.05)$ of $\mathrm{DM}$, $\mathrm{OM}, \mathrm{CP}, \mathrm{CF}$, fiber fractions and TDN insignificantly decreased DCP. These results are matched with chemical composition of the experimental rations.

It is clear that probiotic supplementation to ration (R3) insignificantly ( $\mathrm{P}>0.05)$ improved the digestibilities of most nutrients and fiber fractions and nutritive values as TDN and DCP compared to R2. In this conection, Ali (2005), Gaafar et al. (2005) and Kholif and Khorshed (2006) recorded an increase in CP and CF digestibilities with probiotic supplementation. Whitley et al. (2009) also reported an improvement in apparent digestibilities of DM, CP, NDF and ADF in goats fed diet supplemented with commercial probiotics. However, Titi et al. (2008) reported that addition of probiotics (yeast culture) had no effect on digestibility of DM, CP and NDF. These results might be due to the positive effect of probiotic supplementation on cellulolytic activity by increasing numbers of ruminal fibrolytic microbes and rumen microbial protein synthesis (Martin and Nisbet, 1990, Yoon and Stern, 1996, Nsereko et al., 2002 and Tricarico et al., 2005).

\section{Rumen liquor parameters:}

Results concerning the effect of experimental rations and sampling time on rumen liquor parameters are shown in Table (4). Inclusion of GBP in rations either with (R3) or without (R2) probiotic had no significant effects ( $>0.05)$ on ruminal $\mathrm{pH}$ and TVFA's values compared with control (R1). The result concerning probiotic supplementation coincides with those obtained by Yoon and Stern (1996), Ali 
(2005) and Abd El-Wahed (2007). However, Mohamed et al. (2009), Paryad and Rashidi (2009) and Khalid et al. (2011) observed an increase in ruminal $\mathrm{pH}$ value when probiotic was added.

On the other hand, ruminal $\mathrm{NH}_{3}-\mathrm{N}$ concentrations were significantly higher $(\mathrm{p}<0.05)$ in $\mathrm{R} 2$ and $\mathrm{R} 3$ compared to $\mathrm{R} 1$. The increase in ruminal $\mathrm{NH}_{3}-\mathrm{N}$ with probiotic supplementation might have been associated with a stimulation of proteolytic activity of rumen bacteria (Oeztuerk, 2009). Yoon and Stern (1996) reported that the addition of $57 \mathrm{~g} / \mathrm{d}$, Diamond V XP yeast culture increased numbers of proteolytic bacteria. It has been suggested that the increasing in bacterial population is central to the action of the yeast (Newbold et al., 1996). The most famous theory was suggested by Oeztuerk, 2009 that yeast culture provides various growth factors, pro-vitamins, and/or micronutrients and removes potentially harmful oxygen from the rumen environment.

\section{Blood parameters:}

Results of blood plasma total protein, globulin, total lipids, glucose, urea, creatinine and AST concentrations in Table (5) did not show any significant differences among rations. However, R2 showed significant difference $(\mathrm{p}<0.05)$ with blood albumin, triglyceride and ALT concentrations compared with other rations.

Table (4): Effect of the experimental rations on rumen parameters of growing goat kids

\begin{tabular}{lccccc}
\hline \multirow{2}{*}{ Item } & Sampling time, & \multicolumn{3}{c}{ Experimental rations } & \\
\cline { 3 - 5 } & hrs. & R1 & R2 & R3 & \\
\hline & 0 & 6.89 & 6.87 & 6.84 & 0.08 \\
$\mathrm{pH}$ & 3 & 5.98 & 5.91 & 5.69 & 0.19 \\
& 6 & 6.09 & 6.03 & 5.86 & 0.19 \\
& Mean & 6.32 & 6.27 & 6.13 & 0.12 \\
$\mathrm{NH}_{3}$-N, mg/100 ml rumen liquor & 0 & $35.40^{\mathrm{b}}$ & $39.80^{\mathrm{ab}}$ & $42.60^{\mathrm{a}}$ & 1.47 \\
& 3 & $36.40^{\mathrm{c}}$ & $43.40^{\mathrm{b}}$ & $61.60^{\mathrm{a}}$ & 1.40 \\
& 6 & $53.20^{\mathrm{c}}$ & $60.20^{\mathrm{b}}$ & $67.50^{\mathrm{a}}$ & 1.63 \\
TVFA, mleq/100 ml rumen & Mean & $41.67^{\mathrm{c}}$ & $47.80^{\mathrm{b}}$ & $57.23^{\mathrm{a}}$ & 0.88 \\
liquor & 0 & 14.10 & 13.20 & 13.00 & 0.77 \\
& 3 & 15.90 & 18.00 & 17.80 & 0.92 \\
& 6 & 15.30 & 15.30 & 16.50 & 0.62 \\
\hline
\end{tabular}

$a, b, c \ldots . .$. Means in the same row with different superscript are significantly different $(P<0.05)$.

R1: Control ration (Concentrate feed mixture + Clover hay).

R2: clover hay plus CFM substituted with $20 \%$ GBP.

R3: clover hay plus CFM substituted with $20 \%$ supplemented with $5 \mathrm{~g} / \mathrm{h} / \mathrm{d}$ probiotic.

Table (5): Effect of the experimental rations on blood plasma parameters of growing goat kids

\begin{tabular}{|c|c|c|c|c|}
\hline \multirow{2}{*}{ Item } & \multicolumn{3}{|c|}{ Experimental rations } & \multirow[b]{2}{*}{$\pm \mathrm{SE}$} \\
\hline & R1 & $\mathrm{R} 2$ & R3 & \\
\hline Total proteins, $\mathrm{g} / \mathrm{dl}$ & 5.58 & 5.36 & 5.70 & 0.29 \\
\hline Albumin, $\mathrm{g} / \mathrm{dl}$ & $3.88^{\mathrm{b}}$ & $4.21^{\mathrm{ab}}$ & $4.71^{\mathrm{a}}$ & 0.23 \\
\hline Globulin, g/dl & 1.71 & 1.16 & 0.99 & 0.41 \\
\hline Triglyceride, mg/dl & $1.19^{\mathrm{ab}}$ & $1.79^{\mathrm{a}}$ & $0.61^{\mathrm{b}}$ & 0.20 \\
\hline Total lipid, mg/dl & 1138.21 & 1157.18 & 1146.34 & 63.36 \\
\hline Glucose, g/dl & 66.35 & 59.31 & 49.29 & 5.44 \\
\hline Urea, mg/dl & 28.63 & 18.53 & 12.94 & 5.10 \\
\hline Creatinine, $\mathrm{mg} / \mathrm{dl}$ & 0.97 & 1.01 & 1.06 & 0.03 \\
\hline AST, IU/L & 57.82 & 74.02 & 66.39 & 10.50 \\
\hline ALT, IU/L & $8.19^{b}$ & $11.64^{\mathrm{a}}$ & $7.94^{\mathrm{b}}$ & 0.24 \\
\hline $\begin{array}{l}a, b, \ldots . . . \text { Means in the } \\
\text { transferase and AST: } \\
\text { R1: Control ration (Co } \\
\text { R2: clover hay plus } C F \\
\text { R3: clover hay plus } C F\end{array}$ & e signific & ifferent $(I$ & 55). ALT: & in amine \\
\hline
\end{tabular}




\section{Ghoneem and Mahmoud}

The blood urea and glucose concentrations were insignificantly the lowest with combination of GBP and probiotic (R3) compared to R1 and R2. However, Abo El-Nor and Kholif (1998) reported higher blood urea nitrogen values in response to probiotics supplementation. The lower blood plasma urea nitrogen with probiotics supplementation could be due to improved utilizing of $\mathrm{N}$ in the rumen (Bruno et al., 2009). The lower blood glucose in $\mathrm{R} 2$ and $\mathrm{R} 3$ might be attributed to higher fiber digestion leading to more production of ketogenic moieties.

Generally, all blood plasma parameters were within the normal range mentioned by Merck (2014). Blood parameters regarding kidneys and liver functions had no adverse impact on animal health.

\section{Growth performance:}

No significant differences were noticed among treatments in final body weight, total body weight gain and average daily gain (Table 6). The GBP and probiotic (R3) insignificantly increased total and daily weight gain being $6.36 \mathrm{~kg}$ and $70.66 \mathrm{~g} / \mathrm{d}$, respectively compared to $5.50 \mathrm{~kg}$ and $61.10 \mathrm{~g} / \mathrm{d}$ in R2, in the same order. This slight improvement in R3 compared to R2 may be a result of improving DM, OM, CF digestibilities and nutritive values as TDN and DCP when probiotic was added. Also, higher body weight gain with probiotic supplementation might be due to more cellulolytic activity resulting in improvement of fiber degradation (Russell and Wilson, 1996). Titi et al. (2008) reported that yeast supplementation had no effect on growth rate in lambs and kids. Baranowski et al. (2007) and Whitley et al. (2009) also found the same results with probiotic supplementation. While, Erasmus et al. (1992) and Haddad and Goussous (2005) found that probiotics supplementation tended to increase weight gain in lambs.

Table (6): Effect of the experimental rations on growth performance of growing goat kids and economical efficiency

\begin{tabular}{|c|c|c|c|c|}
\hline \multirow{2}{*}{ Item } & \multicolumn{3}{|c|}{ Experimental rations } & \multirow[b]{2}{*}{$\pm \mathrm{SE}$} \\
\hline & R1 & R2 & R3 & \\
\hline \multicolumn{5}{|l|}{ Live body weight: } \\
\hline Initial body weight, $\mathrm{kg}$ & 15.80 & 15.00 & 14.40 & 0.95 \\
\hline Final body weight, $\mathrm{kg}$ & 22.68 & 20.50 & 20.76 & 1.05 \\
\hline Total weight gain, $\mathrm{kg}$ & 6.88 & 5.50 & 6.36 & 0.39 \\
\hline Average daily gain, $\mathrm{g}$ & 76.00 & 61.00 & 70.00 & 4.29 \\
\hline \multicolumn{5}{|l|}{ Feed intake/day: } \\
\hline Concentrate, $\mathrm{g}$ & $385^{\mathrm{a}}$ & $292^{b}$ & $299^{\mathrm{b}}$ & 16.44 \\
\hline Roughage, g & $250^{\mathrm{a}}$ & $220^{\mathrm{b}}$ & $219^{\mathrm{b}}$ & 5.57 \\
\hline Total DMI, g & $635^{\mathrm{a}}$ & $512^{\mathrm{b}}$ & $518^{\mathrm{b}}$ & 16.34 \\
\hline TDN intake, $g$ & $458^{\mathrm{a}}$ & $359^{\mathrm{b}}$ & $374^{\mathrm{b}}$ & 21.05 \\
\hline \multicolumn{5}{|l|}{ Feed conversion, g/g: } \\
\hline DMI/ daily gain & $8.31^{\mathrm{a}}$ & $8.38^{\mathrm{a}}$ & $7.33^{\mathrm{b}}$ & 0.18 \\
\hline TDN intake / daily gain & $6.04^{\mathrm{a}}$ & $5.87^{\mathrm{ab}}$ & $5.29^{b}$ & 0.13 \\
\hline \multicolumn{5}{|l|}{ Economic efficiency } \\
\hline Feeding cost, LE/h/d & 1.40 & 1.23 & 1.17 & ---- \\
\hline Gain price, LE/h/d & 2.75 & 2.20 & 2.54 & ---- \\
\hline Profit, LE/h/d & 1.35 & 0.97 & 1.37 & ---- \\
\hline Relative (profit/feeding cost \%) & 0.96 & 0.76 & 1.17 & ---- \\
\hline Economic improvement & 100 & 79.16 & 121.87 & ---- \\
\hline
\end{tabular}

Regarding feed intake, kids fed rations containing GBP (R2 or R3) had significantly ( $<<0.05)$ lower intake of concentrate, roughage, total DM and TDN intakes compared with those fed control ration (R1). However, R3 was insignificantly higher than R2 in total intake of DM and TDN. The positive effect of 
yeast supplementation on total DM and TDN intakes could be attributed to high nutrients and fiber fraction digestibility's and TDN value. Similarly, Chademana and Offer (1990), Chiofalo et al. (2004) and Desnoyers et al. (2009) reported a promoting role of probiotics on dry matter intake. However, Titi et al. (2008) observed no effect on DMI when diets of lambs and kids were supplemented with yeast culture. Likewise, Haddad and Goussous (2005) and Hernandez et al. (2009) reported similar findings.

Feed conversion ratios (FCR) as DM or TDN/daily gain were the best in R3 compared to R1 and R2. Probiotics have been reported to improve FCR in ruminants (Robinson, 2002, Haddad and Goussous 2005, Abdelrahman and Hunaiti, 2008, Mutassim and Hunaiti, 2008 and Jang et al. 2009). In contrast, Baranowski et al. (2007) observed no effect of probiotic supplementation on FCR.

\section{Economical efficiency:}

Data in Table (6) showed that ration containing GBP plus probiotic (R3) recorded the lowest feed cost $(1.17 \mathrm{LE} / \mathrm{h} / \mathrm{d})$ and the highest economical efficiency either as profit $(1.37 \mathrm{LE} / \mathrm{h} / \mathrm{d})$ or profit/feeding cost $(1.17 \%)$ compared to R1 and R2. In the same trend, Ali (2005) observed an improvement in economical efficiency when lambs were fed ration containing corn stalks plus probiotic.

\section{CONCLUSION}

In view of the obtained results, it could be concluded that addition of commercial probiotic $(5 \mathrm{~g} / \mathrm{h} / \mathrm{d})$ to GBP at a level of $20 \%$ in concentrate feed mixture can improve the performance of growing kids with high economical efficiency.

\section{REFERENCES}

Abd El-Ghani, A.A. (2004). Influence of diet supplementation with yeast (Saccharomyces cerevisiae) on performance of Zaraibi goats. Small Rumin. Res., 52:223-229.

Abd El-Wahed, A.R.R. (2007). Chemical and biological treatments of some agriculture wastes for ruminant nutrition. Ph.D. Thesis, Fac. Agric., Cairo Univ., Egypt, 173 p.

Abdelrahman, M.M. and D.A. Hunaiti (2008). The effect of dietary yeast and protected methionine on performance and trace minerals status of growing Awassi lambs. Livest. Sci., 115: 235-241.

Abo El-Nor, S.A.H. and A.M. Kholif (1998). Effect of supplementation of live yeast culture in the diet on the productive performance of lactating buffaloes. Milchwissenschaft, 53: 663-666.

Adsule, R.N. and Kadam, S.S. Guava (1995). Handbook of fruit science and technology, production composition, storage and processing. In: Salunkhe, D. K.; Kadam, S. S. (Eds.) New York: Marcel Dekker, cap. 9, p. 419-433.

Aguilera, J.F. (1989). Use of Agro-industiral by-products in the feeding of ruminants. Revista Argentina de production animal, 9: 253-267.

Ali, M.A. (2005). Effect of probiotic addition on growth performance of growing lambs fed different roughages. Egypt. J. Nutrition and Feeds, 8(special issue): 567-578.

Aly, A.M. (1981). Studies on the unsoponifiable matter of some vegetable oils. M.Sc. Thesis, Fac. Agric., Minufiya Univ., Egypt.

AOAC. (2000). Official Methods of Analysis, $17^{\text {th }}$ ed. Association of Official Analytical Chemists, Washington, DC, USA.

Baranowski, A.M.; Gabryszuk, A. Jozwik; E. Bernatowicz and W. Chylinski (2007). Fattening performance, slaughter indicators and meat chemical composition in lambs fed the diet supplemented with linseed and mineral bioplex. Anim. Sci. Papers Rep., 25: 35-44.

Bruno, R.G.S.; H.M. Rutigliano; R.L.Cerri; P.H. Robinson and E.P. Santos (2009). Effect of feeding Saccharomyces Cerevisiae on performance of dairy cows during summer heat stress. Anim. Feed Sci. Tech., 150: 175-186. 


\section{Ghoneem and Mahmoud}

Chademana, I. and N.W. Offer (1990). The effect of dietary inclusion of yeast culture on digestion in the sheep. J. Anim. Prod., 50: 483-489.

Chiofalo, V.; L. Liotta and B. Chiofalo (2004). Effects of the administration of lactobacilli on body growth and on the metabolic profile in growing Maltese goat kids. Reprod. Nutr. Dev., 44: 449-457.

Cunniff, P. Ed. (1997). Official Methods of Analysis of AOAC International. Maryland. USA.

Desnoyers, M.; S. Giger-Reverdin; G. Bertin; C. Duvaux-Ponter and D.Sauvant (2009). Meta-analysis of the influence of Saccharomyces cerevisiae supplementation on ruminal parameters and milk production of ruminants. J. Dairy Sci., 92: 1620-1632.

Doumas, B.T.; W. Watson and H.G. Biggs (1971). A method for determination of Albumin. Clin. Chem. Acta., 31: 87-93.

Duncan, C.B. (1955). Multiple range and multiple F test. Biometrics. 11: 1-42.

El-Deek, A.A.; Safa, M. Hamdy; Y.A. Attia and A.M. El-Shahat (2009). Guava by-product meal processed in various ways and fed in differing amounts as a component in laying hen diets. International J. Poultry Sci., 8: 866-874.

Erasmus, L.J.; P.M. Botha and A. Kistner (1992). Effect of yeast culture supplement in production, rumen fermentation and duodenal nitrogen flow in dairy cows. J. Dairy Sci., 75: 3056-3065.

Gaafar, H. M. A.; A.A. Shitta and E.A. Omer (2005). Probiotic supplementation for suckling Friesian calves. 1- Productive performance. Egypt. J. Nutri. and Feeds, 8(2): 163-173.

Haddad, S.G. and S.N. Goussous (2005). Effect of yeast culture supplementation on nutrient intake, digestibility and growth performance of Awassi lambs. Anim. Feed Sci. Tech., 118: 343-348.

Hernandez, R.; S.S. Gonzalez; J. M. Pinos-Rodrigues; M.A. Ortega; A. Hernandez; G.Bueno and M. Cobos (2009). Effect of yeast culture on nitrogen balance and digestion in lambs fed early, and mature orchard grass. J. Appl. Anim. Res., 32: 53-56.

Holland, B.; A.A. Welch; I.D. Unwin; D. H. Buzz; A. A. Paul and A.T. Southgate (1991). McCance and Widdowson's, The Composition of Foods. UK: The royal Society of Chemistry and Ministry of Agriculture, Fishers and Food.

Jang, D.; Y. Oh; H. KyongPiao; L. GuoChoi; H. BongYun; J. HyeonKim and Y. Yong (2009). Evaluation of Probiotics as an Alternative to Antibiotic on Growth Performance, Nutrient Digestibility, Occurrence of Diarrhea and Immune Response in Weaning Pigs. J. Anim. Sci. Tech., 51: 751-759.

Karkoodi, K.; H. Fazaeli and S.S. Mirghaffari (2012). Assessing the nutritive value of fruit and vegetable residues as ruminant feed. Turk. J. Vet. Anim. Sci., 36: 239-244.

Khalid, M.F.; M.A. Shahzad; M. Sarwar; A.U. Rehman; M. Sharif and N. Mukhtar (2011). Probiotics and lamb performance: A review. African Journal of Agricultural Research, 6(23): 5198-5203.

Khattab, H.M.; H.M. Gado; A.E. Kholif; A. M. Mansour and A.M. Kholif (2011). The potential of feeding goats sun dried rumen contents with or without bacterial inoculums as replacement for berseem clover and the effects on milk production and animal health. Int. J. Dairy Sci. 6: 267-277.

Kholif, S.M. and M.M. Khorshed (2006). Effect of yeast or selenized yeast supplementation to rations on the productive performance of lactating buffaloes. Egypt. J. Nutri. and Feeds, 9(2): 193-205.

Marquina, V.; L. Araujo; J. Ruíz; A. Rodríguez-Malaver and P. Vit (2008). Composition and antioxidant capacity of the guava (Psidium guajava L.) fruit, pulp and jam. Archive Latinoam Nutri., 58: 98-102.

Martin, S.A. and D.J. Nisbet (1990). Effect of Aspergillus Oryzae fermentation extract on fermentation of amino acids and starch by mixed ruminal microorganisms in vitro. J. Anim. Sci., 68: 2142-2149.

Merck (2014). The Merck Veterinary Manual. http://www.merckmanuals.com/vet/appendixes/reference_guides/serum_biochemical_reference_range s.html

Mohamed, M.I.; Y.A. Maareck; S.S. Abdel-Magid and I.M. Awadalla (2009). Feed intake, digestibility, rumen fermentation and growth performance of camel fed diets supplemented with a yeast culture or zinc bacitracin. Anim. Feed Sci. Tech., 149:341-345. 
Mutassim, M. and D.A. Hunaiti (2008).The effect of dietary yeast and protected methionine on performance and trace minerals status of growing Awassi lambs. Livest. Sci., 115: 235-241.

NewBold, C.J.; R.J. Wallace and F.M. Mcintosh (1996). Mode of action of yeast Saccharomyces cerevisiae as a feed additive for ruminants. Brit. J. Nutri., 76: 249-261.

NRC (1981). Nutrient requirement of goats. Angora, dairy and meat goats in temperate and tropical countries. In: Nutrient requirements of domestic animals number 15. National Academy Press, Washington DC, USA.

Nsereko, V.L.; K.A. Beauchemin; D.P. Morgavi; L.M. Rode; A.F. Furtado; T.A. McAllister; A.D. Iwaasa; W. Z. Yang and Y. Wang (2002). Effect of a fibrolytic enzyme preparation from Trichoderma longibrachiatum on the rumen microbial population of dairy cows. Can. J. Microbiol. 48: 14-20.

Oeztuerk, H. (2009). Effects of live and autoclaved yeast cultures on ruminal fermentation in vitro. J. Anim. Feed Sci, 18, 142-150.

Opute, E.I. (1978). The component fatty acids of psidiuym guayava seedless. J. Sci. Food Agric., 29: 737.

Paryad, A. and M. Rashidi (2009). Effect of yeast (Saccharomycescerevisiae) on apparent digestibility and nitrogen retention of Tomato Pomace in sheep. Pak. J. Nut., 8: 273-278.

Patton, F.G. and S.R. Grouch (1977). Colorimetric determination of urea. Anal. Chem., 49: 464-468.

Preston, T.A. (1995). Tropical Animal Feeding - A Manual for Research Worker. FAO Animal Production and Health Paper 126. Rome. http://www.fao.org/ag/aga/agap/frg/AHPP126/ahpp126.htm

Robinson, P.H. (2002). Yeast products for growing and lactating dairy cattle: Impact on rumen fermentation and performance. Dairy Rev., 9: 1-4.

Rolfe, R.D. (2000). The role of probiotic cultures in the control of gastrointestinal health. J. Nutri., 130: 396S-402S.

Russell, J.B. and D.B. Wilson (1996). Why are ruminal cellulolytic bacteria unable to digest cellulose at low pH. J. Dairy Sci., 79: 1503-1510.

SAS (2001). User's guide. Statistic. Ver.8.02, SAS Institute Inc., Cary, NC, USA

Tietz, N.W. (1986). Text Book of Clinical Chemistry. W.B. Saunders, Philadelphia, Pages: 1271.

Tietz, N.W. P.R. Finley, E. Pruden and A.B. Amerson (1990). Clinical Guide to Laboratory Tests. $2^{\text {nd }}$ Edn., W.B. Sunders Co., Philadelphia, Pages: 931.

Titi, H.H.; R.O. Dmour and A.Y. Abdullah (2008). Growth performance and carcass characteristics of Awassi lambs and Shami goat kid fed yeast culture in their finishing diet. J. Anim. Sci., 142: 375-383.

Tricarico, J.M.; J.D. Johnston; K.A. Dawson; K.C. Hanson; K.R. McLeod and D.L. Harmon (2005). The effects of an Aspergillus oryzae extract containing alpha-amylase activity on ruminal fermentation and milk production in lactating Holstein cows. Anim. Sci., 81: 365-374.

Van Soest, P.J.; J.B. Robertson and B.A. Lewis (1991). Methods for dietary fiber, neutral detergent fiber, and nonstarch polysaccharides in relation to animal nutrition. J. Dairy Sci. 74: 3583-3597.

Whitley, N.C.; D. Cazac; B. J. Rude; D. Jackson-O’Brien and S. Parveen (2009). Use of commercial Probiotics supplement in meat goat. J. Anim. Sci., 87: 723-728.

Yoon, I.K. and M. D. Stern (1996) Effects of Saccharomyces cerevisiae and Aspergillus orysae culture on ruminal fermentation in dairy cows. J. Dairy Sci., 79: 411-417.

Young, D.S. (1997). Effects of Preanalytical Variables on Clinical Laboratory Tests. $2^{\text {nd }}$ Edn., AACC Press, Washington, DC., USA., Pages: 1285. 


\title{
تأثير العلائق المحتوية على مخلفات الجوافة مع أو بدون محفز النمو على أداء الجداء النامية
}

\author{
وفاء مصطفى على غنيم و عادل عيد محمد محمود
}

قسم الإنتاج الحيو انى، كلية الزر اعة، جامعة القاهرة، 12613 جيزة، مصر

تهدف هذه الدراسة إلى تحديد نأثير إحلال مخلفات الجو افة محل مخلوط العلف المركز بنسبة 20\% مع أو بد بدون البروبيوتيك على أداء

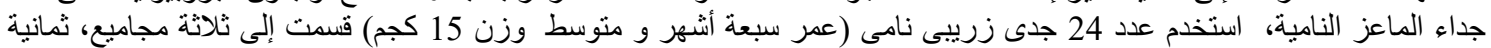

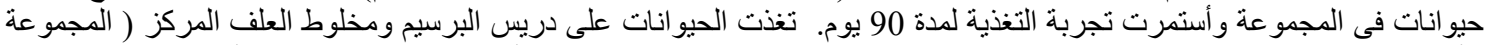

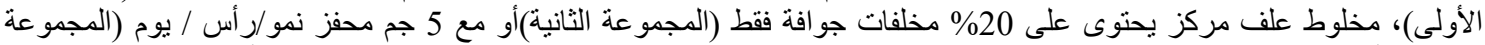

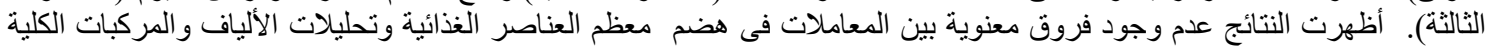

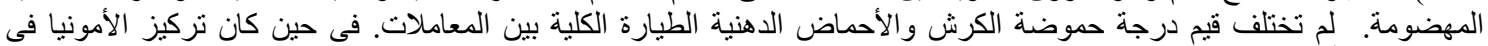

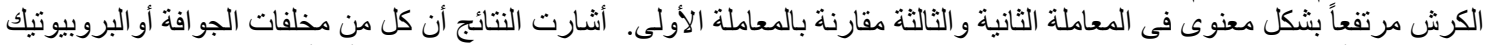

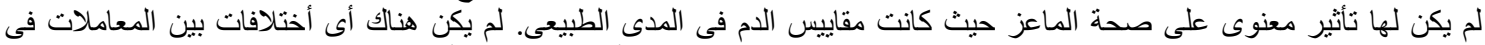

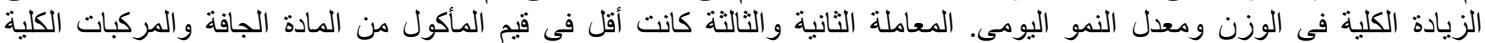

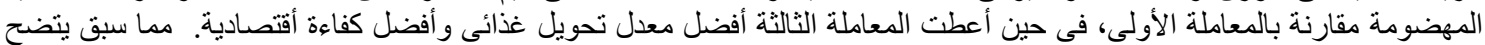

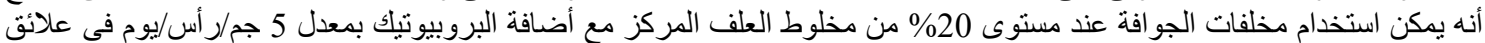
جذاء الماعز النامية بدون أى تأثير ات سلبية على الأداء الأنتاجى مع تحسن فى الكفاءة الأقتصادية. 